\title{
IMPLEMENTASI MODEL TRANSPORTASI DISTRIBUSI PRODUK VAKSIN HEPATITIS B MENGGUNAKAN METODE LEAST COST DAN MODIFIED DISTRIBUTION
}

\author{
Resa Lestari ${ }^{* 1}$, Thyar Romadhon ${ }^{2}$, Muchammad Fauzi ${ }^{3}$ \\ 1,2,3,Program Studi Teknik Industri, Universitas Widyatama Bandung \\ lestari.resa@widyatama.ac.id*1, thyar.romadhon@widyatama.ac.id ${ }^{2}$, \\ muchammad.fauzi@widyatama.ac.id ${ }^{3}$
}

\begin{abstract}
The transportation method is a method related to optimization model used to minimize the cost of transportation distribution. Distribution of products to various regions requires transportation costs are not small, it requires good planning in order for the availability of goods can be met. The purpose of this study, applying the transportation cost of hepatitis B vaccine distribution from PT. XYZ by using Least Cost Method as the initial solution and Modified Distribution Method (MODI) to optimize so that companies can know the cost of optimal vaccine distribution. The results showed the implementation of transportation model by PT. XYZ with the initial solution using the Least Cost Method obtained the cost of transportation distribution of Rp 45,874,100. then after the optimization of costs by using Modified distribution method the cost of transportation distribution becomes more optimal and the minimization of costs obtained to be $R p$ 45,767,100.
\end{abstract}

Keywords: Transportation method, Optimization, Least Cost Method, Modified Distribution Method (MODI).

\begin{abstract}
Abstrak
Metode transportasi merupakan metode yang berkaitan dengan model optimasi yang digunakan untuk meminimumkan biaya transportasi pendistribusian. Pendistribusian produk menuju berbagai daerah memerlukan biaya tranportasi yang tidak murah, sehingga perlunya perencanaan yang baik supaya ketersediaan barang dapat terpenuhi. Tujuan penelitian ini, menerapkan biaya transportasi distribusi vaksin Hepatitis B pada PT. XYZ menggunakan Least Cost Method sebagai solusi awal dan MODI (Modified Distribution Method) untuk mengoptimalkan solusi agar perusahaan dapat melakukan optimasi dengan biaya pendistribusian vaksin yang optimal. Hasil penelitian menunjukan Implementasi model transportasi oleh PT. XYZ dengan solusi awal menggunakan Least Cost Method diperoleh biaya transportasi pendistribusian sebesar Rp 45.874.100. kemudian setelah dilakukan optimalisasi biaya dengan menggunakan Modified Distribution Method biaya transportasi pendistribusian menjadi lebih optimal dan minimalisasi biaya yang diperoleh menjadi sebesar Rp 45.767.100.
\end{abstract}

Kata kunci: Metode transportasi, Optimasi, Least Cost Method, Modified Distribution Method (MODI). 
Jurnal Lebesgue : Jurnal Ilmiah Pendidikan Matematika, Matematika dan Statistika

Resa Lestari, Thyar Romadhon, Muchammad Fauzi

Volume 2, No. 2, Agustus 2021 hal.180-193

DOI Artikel : 10.46306/lb.v2i2.69

\section{PENDAHULUAN}

Metode transportasi merupakan metode yang berkaitan dengan model optimasi yang digunakan untuk meminimumkan biaya transportasi pendistribusian. Dalam proses pendistribusian barang, kapasitas dan ongkos transportasi harus diperhatikan untuk memperoleh distribusi yang efektif dan efisien (Putri \& Putri, 2017). Pendistribusian produk menuju berbagai daerah memerlukan biaya tranportasi yang tidak murah, sehingga dibutuhkannya perencanaan dengan matang (Herlawati, 2016). Proses distribusi yang baik berdasarkan ketersediaan barang yang dapat dipenuhi suatu perusahaan terhadap permintaan konsumen. Distribusi memerlukan alat transportasi untuk menyalurkan, sehingga terdapat biaya distribusi yang dikeluarkan. Dalam distribusi produk oleh perusahaan tentu ditemukan masalah transportasi yang sering terjadi, yaitu menentukan cara pengiriman ke beberapa tujuan dari beberapa sumber yang ada (Irwan \& Yuniral, 2016). Perusahaan yang mengalami permasalahan transportasi proses pendistribusian produk adalah PT. XYZ.

PT. XYZ merupakan perusahaan farmasi yang menghasilkan produk vaksin di Indonesia terletak di Bandung Jawa Barat, sebagai perusahaan yang memproduksi sediaan farmasi khusus yaitu vaksin tentu harus melakukan pendistribusian yang cepat dan ongkos produksi yang rendah sebagai upaya efisiensi untuk meminimumkan biaya transportasi. Upaya penekanan biaya transportasi yang ada saat ini sebesar Rp. 48.055.455/bulan dapat dilakukan dengan teknik perhitungan metode transportasi. Metode penyelesaian awal menggunakan metode biaya terendah (Least Cost), dan dilanjutkan dengan Modified Distribution Method (MODI) sebagai langkah memperoleh solusi optimal dari hasil yang diperoleh metode awal tersebut. Prinsip kerja metode Least Cost dengan memberi prioritas alokasi dengan ongkos satuan biaya dari unit terkecil (Sari, 2015). MODI atau Modified Distribution Method merupakan metode penyelesaian kasus transportasi yang dikembangkan dari metode Stepping Stone (Nelwan et al., 2013). Tujuan penelitian yaitu menerapkan biaya distribusi dari vaksin Hepatitis B pada PT. XYZ dengan menggunakan metode Least Cost dan Modified Distribution Method atau MODI agar perusahaan dapat melakukan optimasi dengan biaya pendistribusian vaksin yang optimal.

Penelitian dilakukan terhadap PT. XYZ sebagai salah satu produsen vaksin Hepatitis B yang didistribusikan ke sejumlah provinsi di Indonesia yaitu Jawa Tengah, Jakarta, dan Banten untuk memperoleh ongkos distribusi paling optimal. Produk vaksin Hepatitis B memiliki 3 gudang persediaan PT. XYZ terdapat di 3 wilayah yaitu Jl. Pasteur Kota Bandung, Jl Gatot Subroto Kota Bandung, dan Jl Cisarua Lembang Kabupaten Bandung Barat. Ongkos transportasi dihitung berdasarkan jarak, volume pengiriman produk, biaya pengemudi dan perawatan alat transportasi. 
Jurnal Lebesgue : Jurnal Ilmiah Pendidikan Matematika, Matematika dan Statistika

Resa Lestari, Thyar Romadhon, Muchammad Fauzi

Volume 2, No. 2, Agustus 2021 hal.180-193

DOI Artikel : 10.46306/lb.v2i2.69

\section{METODE PENELITIAN}

Data distribusi vaksin Hepatitis B menuju wilayah provinsi yaitu Jawa Tengah, Jakarta, dan Banten pada Tahun 2021 oleh PT. XYZ. Variabel yang diperhatikan yaitu kebutuhan vaksin di setiap provinsi, biaya yang dibutuhkan dalam pengiriman tiap bulan, dan kapasitas produksi dari pabrik dengan lokasi yang berbeda yaitu Jl. Pasteur Kota Bandung, Jl Gatot Subroto Kota Bandung, dan Jl Cisarua Lembang Kabupaten Bandung Barat.

\section{Prosedur Analisis}

1. Mengumpulkan data perusahaan mengenai permintaan vaksin di setiap wilayah, kapasitas angkut alat tranportasi, dan biaya distribusi yang dibutuhkan untuk pengiriman.

2. Mengolah data menjadi tabel transportasi awal, kemudian melakukan perhitungan awal dengan metode Least Cost.

3. Memperoleh solusi di awal dari model transportasi berdasarkan syarat yaitu

$M-n+1$

Keterangan:

$\mathrm{m}$ = banyaknya baris terisi

$\mathrm{n}=$ banyaknya kolom terisi

4. Melakukan perhitungan lanjutan dari hasil perhitungan solusi awal menggunakan metode Modified Distribution (MODI).

5. Memperoleh hasil optimal biaya transportasi.

\section{Operasi Riset}

Riset Operasi merupakan teknik dalam mencari solusi dengan tindakahan memperoleh solusi optimal dan dari keputusan yang diambil dengan sumber daya yang terbatas. (Mulyono, 2007). Riset operasi tersusun dari dua kata yaitu kata "riset" dan "operasi", riset yaitu melakukan penelitian dengan menggunakan metode ilmiah sedangkan operasi merupakan proses suatu kegiatan produksi, proses pengiriman (Tirta \& Perkasa, n.d.). Riset dalam suatu perusahaan dilakukan bedasarkan input terbatas dan diharapkan memperoleh output atau hasil yang semaksimal mungkin.

\section{Model Transportasi}

Model transportasi pertama kali dikenali dengan diselesaikan secara manual dengan menggunakan algoritma yang dikenal sebagai algoritma transportasi (Ardiansyah, 2014). Langkah pengerjaan model transportasi. 
Jurnal Lebesgue : Jurnal Ilmiah Pendidikan Matematika, Matematika dan Statistika

Resa Lestari, Thyar Romadhon, Muchammad Fauzi

Volume 2, No. 2, Agustus 2021 hal.180-193

DOI Artikel : 10.46306/lb.v2i2.69

1. Dilakukan diagnosis masalah dengan mengenali sumber, tujuan, parameter, dan variabel yang digunakan.

2. Dibentuk matriks dari informasi yang diperoleh menjadi transportasi matriks, Dalam hal ini:

a. Jila seluruh kapasitas sumber lebih dari permintaan tujuan maka ditambhakan kolom (dummy) untuk menampung kelebihan kapasitas.

b. Sama halnya dengan permintaan, jika permintaan lebih banyak dibandingkan kapasitasnya, maka harus ditambahkan baris (dummy) untuk memenuhi kelebihan permintaan

3. Langkah selanjutnya adalah memecahkan masalah transportasi yaitu dengan menyusun algoritma pada tabel awal, model transportasi ini teridiri dari tiga metode diantaranya:

a. Least Cost Method atau Metode Biaya Terkecil

b. North West Corner Rule Method atau Metode Sudut Barat Laut

c. Vogel's Approximation Method atau VAM

Setiap metode memiliki fungsi yaitu menentukan pendistribusian awal berdasarkan kapasitas dan sumber ke semua tujuan.

4. Jika tabel awal sudah selesai maka akan dilakukan langkah selanjutnya yaitu pengujian optimalisasi hasil untuk mengetahui distribusi yang dilakukan sudah optimal atau masih terdapat kemungkinan hasil paling minimum. Terdapat dua macam pengujian optimalitas alogaritma transportasi.

a. Metode batu loncatan atau Stepping Stone Method)

b. MODI atau Modified Distribution

5. Selanjutnya yaitu melakukan modifikasi tabel jika pada langkah sebelumnya masih terdapat kemungkinan hasil yang lebih minimal.

\section{Metode Least Cost}

Metode least cost memiliki prinsip kerja yaitu pemberian prioritas dalam pengalokasian yang memiliki ongkos satuan terkecil biaya per unit terkecil (Nelwan et al., 2013). Alokasi awal dilakukan pada kotak dalam tabel yang memiliki biaya terendah. Berikut langkah dalam pengerjaan metode least cost, yaitu:

a. Dialokasikan ke kotak feasible sebanyak mungkin dengan minimal biaya transportasi dan disesuaikan berdasarkan kapasitas yang ada.

b. Kemudian diulangi langkah tersebut dengan biaya transportasi yang paling rendah selanjutnya. 
Jurnal Lebesgue : Jurnal Ilmiah Pendidikan Matematika, Matematika dan Statistika

Resa Lestari, Thyar Romadhon, Muchammad Fauzi

Volume 2, No. 2, Agustus 2021 hal.180-193

DOI Artikel : 10.46306/lb.v2i2.69

\section{Metode Modified Distribution Method (MODI)}

MODI yaitu metode dengan algoritma stepping stone atau batu loncatan dengan penghalusan. MODI menghitung dengan cara meningkatkan nilai atau indeks dan tidak menggambarkan seluruh jejak yang ditutup. Jejak tersebut digambarkan setelah ditemukannya sel dengan indeks atau nilai negative paling besar. (Matematika et al., 2019).

Digunakan rumus dalam memilih nilai tersebut, yaitu: (Setyawam \& Wicaksono, 2007).

$R a+K b=C a b$

Keterangan:

$\mathrm{Ra}=$ nilai baris ke $\mathrm{a}$

$\mathrm{Kb}=$ nilai kolom $\mathrm{b}$

$\mathrm{Cab}=$ ongkos transportasi untuk satu satuan barang dari sumber a menuju $\mathrm{b}$.

Berikut langkah dalam menghitung dengan metode MODI, diantaranya:

1. Dibuat tabel awal yaitu tabel model transportasi yang menggambarkan keterhubungan antara kapasitas pabrik dengan permintaan yang dituju, dan ongkos transportasi dengan jumlah kebutuhan setiap tujuan diletakkan pada baris paling akhir dan kapasitas tiap pabrik diletakan di kolom paling akhir, dan terakhir yaitu ongkos transportasi diletakkan di pojok paling atas sebelah kiri.

2. Dilakukan pemeriksaan apakah total supply dengan total demand sama, jika tidak sama maka tambahkan kolom "Dummy”. Jik jumlah demand lebih dari supply maka tambahkan baris semu untuk supply dan sebaliknya juga untuk demand lebih sedikit dibandingkan supply maka tambahkan nilai semu pada demand.

3. Produk dialokasika dari sumber menuju tujuan berdasarkan metode awal yaitu metode Least Cost.

4. Ditentukan nilai Ui untuk tiap baris dan $\mathrm{Vj}$ untuk tiap kolom dengan menggunakan hubungan:

$$
C a b=U a+V b
$$

untuk setiap variabel basis dan tetap nilai nol untuk Ui, dengan keterngan:

$\mathrm{i}=1,2,3, \ldots, \mathrm{n}$

$\mathrm{j}=1,2,3, \ldots, \mathrm{m}$.

$\mathrm{Ua}=$ indeks pada setiap baris atau nilai di tiap baris

$\mathrm{Vb}=$ indeks pada setiap kolom atau nilai di tiap kolom

$\mathrm{Cab}=$ ongkos transportasi atau kapasitas untuk satu satuan barang dari sumber a menuju tujuan b 
Jurnal Lebesgue : Jurnal Ilmiah Pendidikan Matematika, Matematika dan Statistika

Resa Lestari, Thyar Romadhon, Muchammad Fauzi

Volume 2, No. 2, Agustus 2021 hal.180-193

DOI Artikel : 10.46306/lb.v2i2.69

5. Dihitung perbedaan ongkos transportasi (Cab) untuk tiap non-basis varibel dengan menggunakan rumus

$C a b=C a b-U a-U b$

Keterangan:

$\mathrm{Cab}=$ variabel atau indeks non-basis .

6. Ditentukan sel basis dengan memilih sel non-basis yang memiliki nilai terbesar. Digambarkan jalur menutup dengan tujuan menentukan sel sebagai basis dengan memilih jumlah unit terkecil dari sel yang bertanda negatif dan terbentuk sel baru.

7. Hasil yang diperoleh terdapat nilai Cab negatif, solusi yang diperoleh merupakan solusi belum optimal. Dan sebaliknya solusi optimal akan tercapai jika Cab semuanya bernilai positif dimana sel non-basis lebih dari sama dengan nol.

8. Lakukan langkah sebelumnya jika hasil yang diperoleh belum optimal, hingga diperoleh nilai Cab positif.

\section{HASIL DAN PEMBAHASAN}

Data persediaan vaksin Hepatitis B berdasarkan wilayah pengiriman ditunjukan pada tabel 1.

Tabel 1. Data Persediaan Vaksin Hepatitis B

\begin{tabular}{cccc}
\hline No & Gudang & Persediaan & Satuan \\
\hline 1 & $\begin{array}{c}\text { Pasteur, } \\
\text { Bandung }\end{array}$ & 600 & Koli \\
\hline 2 & $\begin{array}{c}\text { Gatot Subroto, } \\
\text { Bandung }\end{array}$ & 355 & Koli \\
\hline 3 & $\begin{array}{c}\text { Cisarua, } \\
\text { Lembang }\end{array}$ & 334 & Koli
\end{tabular}

Data permintaan vaksin Hepatitis B per bulan ditunjukkan pada tabel 2.

Tabel 2. Data Permintaan Vaksin Hepatitis $B$

\begin{tabular}{cccc}
\hline No & $\begin{array}{c}\text { Provinsi } \\
\text { Tujuan }\end{array}$ & Permintaan & Satuan \\
\hline 1 & Jakarta & 340 & Koli \\
\hline 2 & Banten & 374 & Koli \\
\hline 3 & Jawa Tengah & 575 & Koli \\
\hline
\end{tabular}


Jurnal Lebesgue : Jurnal Ilmiah Pendidikan Matematika, Matematika dan Statistika

Resa Lestari, Thyar Romadhon, Muchammad Fauzi

Volume 2, No. 2, Agustus 2021 hal.180-193

DOI Artikel : 10.46306/lb.v2i2.69

Data ongkos transportasi per satuan yang tercantum di Tabel 1 dan 2 yaitu box dari setiap gudang menuju masing-masing lokasi tujuan ditunjukkan pada tabel 3.

Tabel 3. Ongkos Transportasi

\begin{tabular}{cccc}
\hline \multirow{2}{*}{ Sumber } & \multicolumn{3}{c}{ Tujuan } \\
\cline { 2 - 4 } & $\begin{array}{c}\text { Jakarta } \\
(\mathbf{R p} / \mathbf{k o l i})\end{array}$ & $\begin{array}{c}\text { Banten } \\
(\mathbf{R p} / \mathbf{k o l i})\end{array}$ & $\begin{array}{c}\text { Jawa Tengah } \\
(\mathbf{R p} / \mathbf{k o l i})\end{array}$ \\
\hline $\begin{array}{c}\text { Pasteur } \\
\text { Bandung }\end{array}$ & 27.200 & 31.700 & 43.200 \\
\hline $\begin{array}{c}\text { Gatot } \\
\text { Subroto } \\
\text { Bandung }\end{array}$ & 27.300 & 31.600 & 42.700 \\
\hline $\begin{array}{c}\text { Cisarua } \\
\text { Lembang }\end{array}$ & 27.500 & 31.900 & 43.100 \\
\hline
\end{tabular}

Dibuat tabel matriks solusi awal dari data permintaan, persediaan, dan ongkos transportasi.

Tabel 4. Matriks Solusi Awal

\begin{tabular}{|c|c|c|c|c|}
\hline & Jakarta & Banten & Jawa Tengah & \multirow{2}{*}{ Supply } \\
\hline & (D1) & (D2) & (D3) & \\
\hline $\begin{array}{c}\text { Pasteur, } \\
\text { Bandung } \\
\text { (S1) }\end{array}$ & 27200 & 31700 & 43200 & 600 \\
\hline $\begin{array}{c}\text { Gatot } \\
\text { Subroto } \\
\text { Bandung } \\
(\mathrm{S} 2)\end{array}$ & 27300 & 31600 & 42700 & 355 \\
\hline $\begin{array}{c}\text { Cisarua } \\
\text { Lembang }\end{array}$ & 27500 & 31900 & 43100 & 334 \\
\hline Demand & 340 & 374 & 574 & \\
\hline \multicolumn{5}{|c|}{ Tabel 5. Hasil Matriks Metode Least Cost } \\
\hline & $\frac{\text { Jakarta }}{\text { (D1) }}$ & $\frac{\text { Banten }}{\text { (D2) }}$ & $\frac{\text { Jawa Tengah }}{\text { (D3) }}$ & Supply \\
\hline
\end{tabular}


Jurnal Lebesgue : Jurnal Ilmiah Pendidikan Matematika, Matematika dan Statistika

Resa Lestari, Thyar Romadhon, Muchammad Fauzi

Volume 2, No. 2, Agustus 2021 hal.180-193

DOI Artikel : 10.46306/lb.v2i2.69

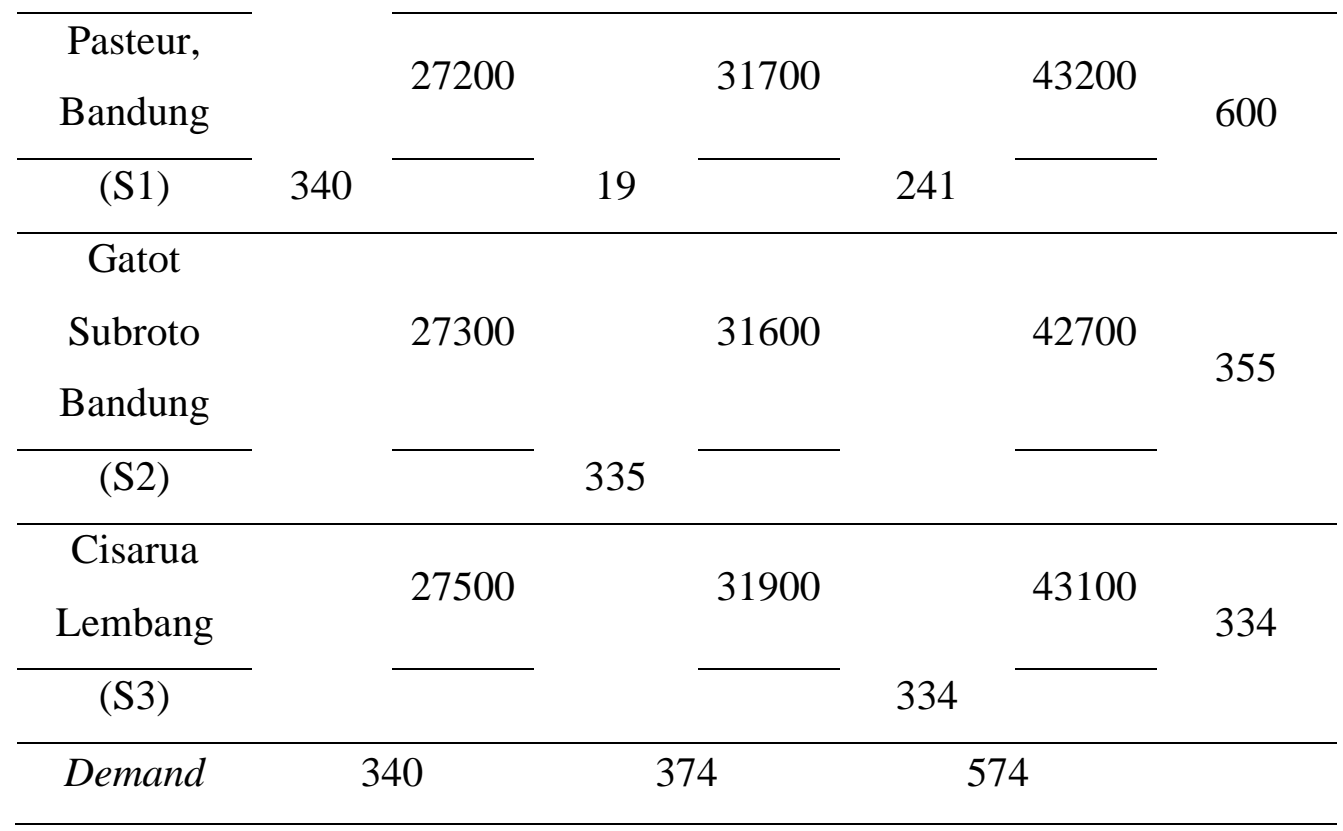

Diperoleh total ongkos transportasi yaitu:

$O T=\sum_{i=1, j=1}^{m, n} C i j . X i j$

$\mathrm{OT}=(27200 \times 340)+(31700 \times 19)+(43200 \times 241)+(31600 \times 355)+(43100 \times 334)$

$\mathrm{OT}=\mathrm{Rp} 45.874 .900$

Variabel basis x11, x12, x13, x22 dan X33 = 5

Jumlah variabel basis $=\mathrm{I}+\mathrm{j}-1=3+3-1=5$

Solusi awal dilakukan dengan metode Least Cost dengan jumlah variabel basis 5 ,

Optimalisasi hasil dengan metode $M O D I$

Iterasi 1

Asumsi nilai $\mathrm{U} 1=0$

1. $\mathrm{C} 11=\mathrm{U} 1+\mathrm{V} 1 \rightarrow \mathrm{V} 1=\mathrm{C} 11-\mathrm{U} 1 \rightarrow \mathrm{V} 1=27200-0 \rightarrow \mathrm{V} 1=27200$

2. $\mathrm{C} 12=\mathrm{U} 1+\mathrm{V} 2 \rightarrow \mathrm{V} 2=\mathrm{C} 12-\mathrm{U} 1 \rightarrow \mathrm{V} 2=31700-0 \rightarrow \mathrm{V} 2=31700$

3. $\mathrm{C} 22=\mathrm{U} 2+\mathrm{V} 2 \rightarrow \mathrm{U} 2=\mathrm{C} 22-\mathrm{V} 2 \rightarrow \mathrm{U} 2=31600-31700 \rightarrow \mathrm{U} 2=-100$

4. $\mathrm{C} 13=\mathrm{U} 1+\mathrm{V} 3 \rightarrow \mathrm{V} 3=\mathrm{C} 13-\mathrm{U} 1 \rightarrow \mathrm{V} 3=43200-0 \rightarrow \mathrm{V} 3=43200$

5. $\mathrm{C} 33=\mathrm{U} 3+\mathrm{V} 3 \rightarrow \mathrm{U} 3=\mathrm{C} 33-\mathrm{V} 3 \rightarrow \mathrm{U} 3=43100-43200 \rightarrow \mathrm{U} 3=-100$

Evaluasi terhadap variabel non-basis:

$D_{i j}=c_{i j}-\left(u_{i}-v_{j}\right)$

1. $\mathrm{D} 21=\mathrm{C} 21-(\mathrm{U} 2+\mathrm{V} 1)=27300-(-100+27200)=200$

2. $\mathrm{D} 23=\mathrm{C} 23-(\mathrm{U} 2+\mathrm{V} 3)=42700-(-100+43200)=-400$

3. $\mathrm{D} 31=\mathrm{C} 31-(\mathrm{U} 3+\mathrm{V} 1)=27500-(-100+27200)=400$ 
Jurnal Lebesgue : Jurnal Ilmiah Pendidikan Matematika, Matematika dan Statistika

Resa Lestari, Thyar Romadhon, Muchammad Fauzi

Volume 2, No. 2, Agustus 2021 hal.180-193

DOI Artikel : 10.46306/lb.v2i2.69

4. $\mathrm{D} 32=\mathrm{C} 32-(\mathrm{U} 3+\mathrm{V} 2)=31900-(-100+31700)=300$

Tabel 6. Hasil Evaluasi Iterasi 1

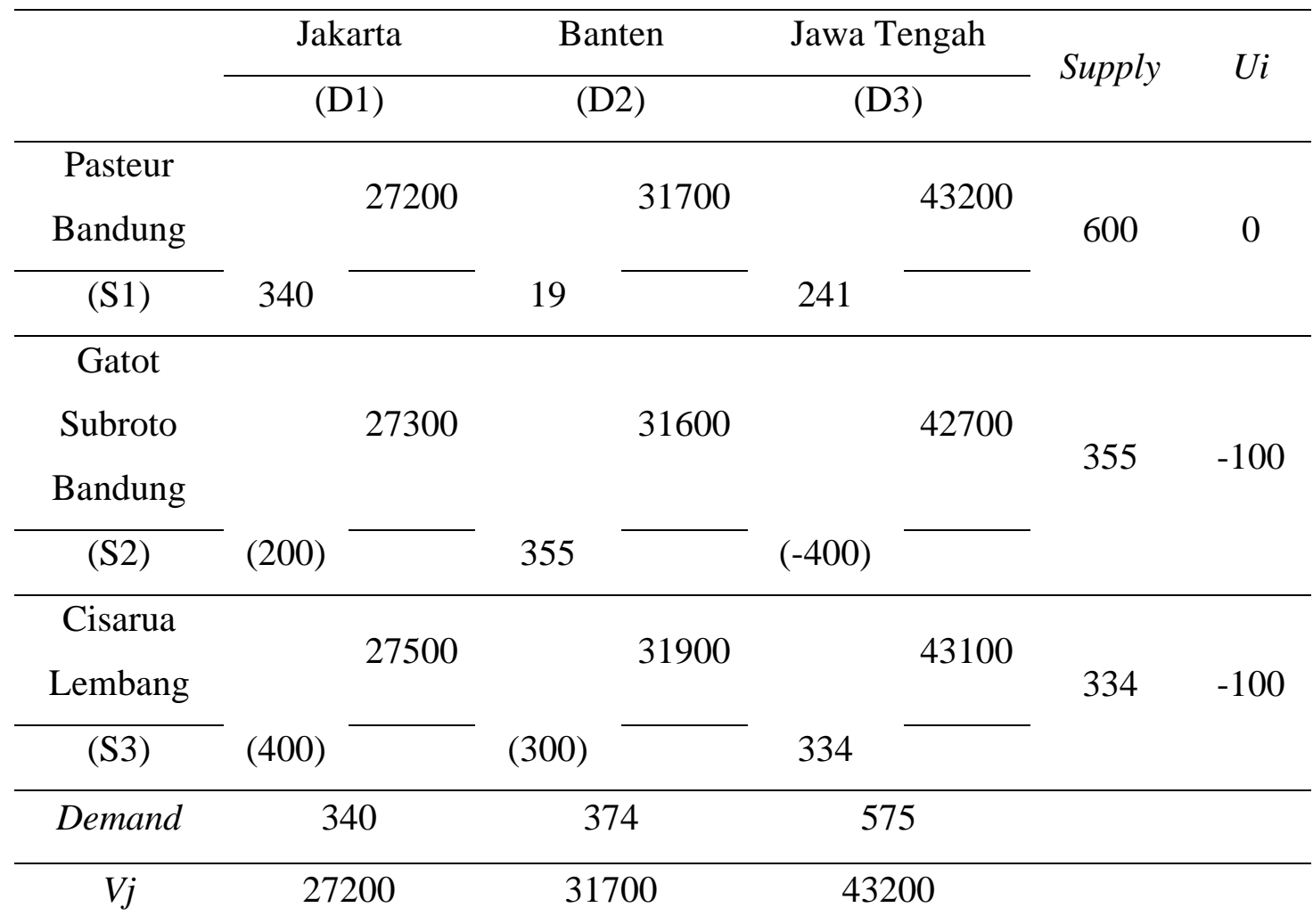

Hasil iterasi 1 terdapat nilai negatif pada variabel non-basis, sehingga solusi yang diperoleh belum optimal. Kemudian pilih negative terkecil pada variabel non-basis yaitu D23 $=-400$, dengan pola S2D3 $\rightarrow$ S2D2 $\rightarrow$ S1D2 $\rightarrow$ S1D1. Jalan terdekat dengan demand terkecil dari D23 yaitu 241 sehingga baris dan kolom terdekat dikurangi dan ditambah sebanyak 241. Berikut hasil dari iterasi 1:

Tabel 7. Hasil Perbaikan MODI Iterasi 1

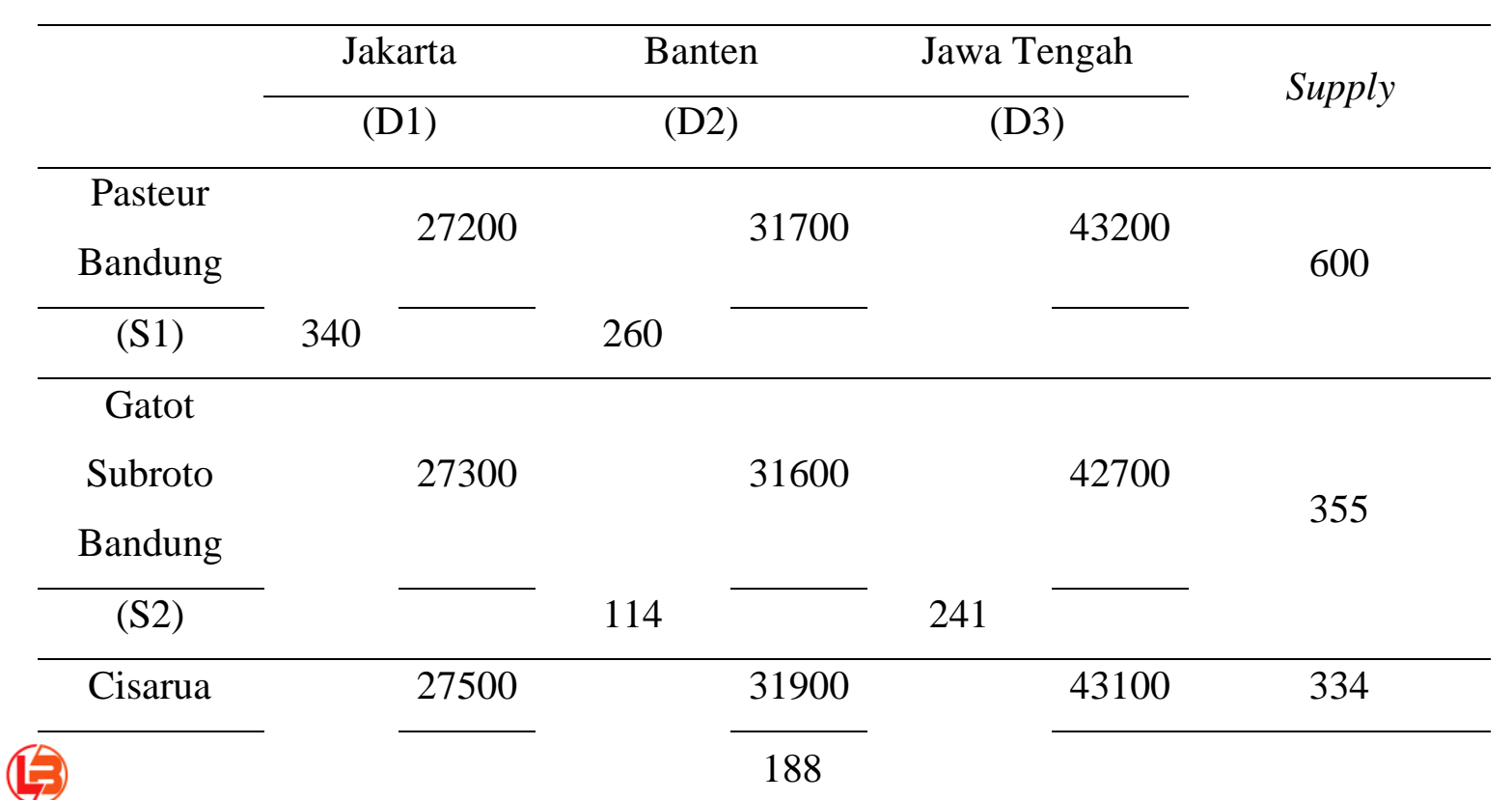




\section{Lembang}

(S3)

\section{4}

Demand $\quad 340 \quad 374 \quad 575$

\section{Iterasi 2}

Asumsi U1 = 0

1. $\mathrm{C} 11=\mathrm{U} 1+\mathrm{V} 1 \rightarrow \mathrm{V} 1=\mathrm{C} 11-\mathrm{U} 1 \rightarrow \mathrm{V} 1=27200-0 \rightarrow \mathrm{V} 1=27200$

2. $\mathrm{C} 12=\mathrm{U} 1+\mathrm{V} 2 \rightarrow \mathrm{V} 2=\mathrm{C} 12-\mathrm{U} 1 \rightarrow \mathrm{V} 2=31700-0 \rightarrow \mathrm{V} 2=31700$

3. $\mathrm{C} 22=\mathrm{U} 2+\mathrm{V} 2 \rightarrow \mathrm{U} 2=\mathrm{C} 22-\mathrm{V} 2 \rightarrow \mathrm{U} 2=31600-31700 \rightarrow \mathrm{U} 2=-100$

4. $\mathrm{C} 23=\mathrm{U} 2+\mathrm{V} 3 \rightarrow \mathrm{V} 3=\mathrm{C} 23-\mathrm{U} 2 \rightarrow \mathrm{V} 3=42700-(-100) \rightarrow \mathrm{V} 3=42800$

5. $\mathrm{C} 33=\mathrm{U} 3+\mathrm{V} 3 \rightarrow \mathrm{U} 3=\mathrm{C} 33-\mathrm{V} 3 \rightarrow \mathrm{U} 3=43100-42800 \rightarrow \mathrm{U} 3=300$

Evaluasi variabel non-basis :

$D_{i j}=c_{i j}-\left(u_{i}-v_{j}\right)$

1. $\mathrm{D} 13=\mathrm{C} 13-(\mathrm{U} 1+\mathrm{V} 3)=43200-(0+42800)=400$

2. $\mathrm{D} 21=\mathrm{C} 21-(\mathrm{U} 2+\mathrm{V} 1)=27300-(-100+27200)=200$

3. $\mathrm{D} 31=\mathrm{C} 31-(\mathrm{U} 3+\mathrm{V} 1)=27500-(300+27200)=0$

4. $\mathrm{D} 32=\mathrm{C} 32-(\mathrm{U} 3+\mathrm{V} 2)=31900-(300+31700)=-100$

Tabel 8. Hasil Evaluasi Iterasi 2

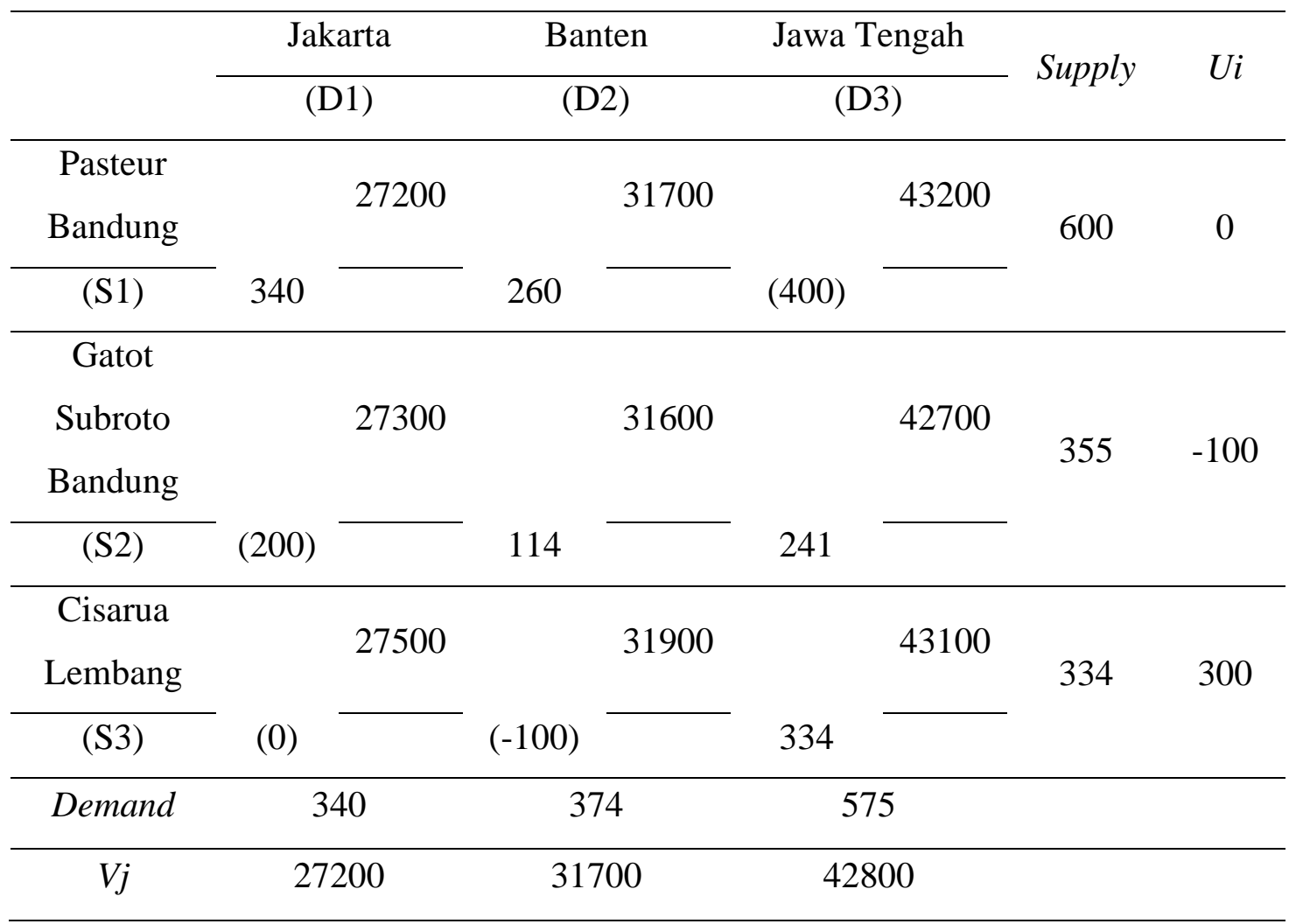


Jurnal Lebesgue : Jurnal Ilmiah Pendidikan Matematika, Matematika dan Statistika

Resa Lestari, Thyar Romadhon, Muchammad Fauzi

Volume 2, No. 2, Agustus 2021 hal.180-193

DOI Artikel : 10.46306/lb.v2i2.69

Hasil iterasi 2 terdapat nilai negatif pada variabel non-basis, sehingga solusi yang diperoleh belum optimal. Kemudian pilih negative terkecil pada variabel non-basis yaitu D32 $=-100$, dengan pola S3D2 $\rightarrow$ S3D3 $\rightarrow$ S2D3 $\rightarrow$ S2D2. Jalan terdekat dengan demand terkecil dari D32 yaitu 114 sehingga baris dan kolom terdekat dikurangi dan ditambah sebanyak 114. Berikut hasil iterasi 2 :

Tabel 9. Hasil Perbaikan MODI Iterasi 2

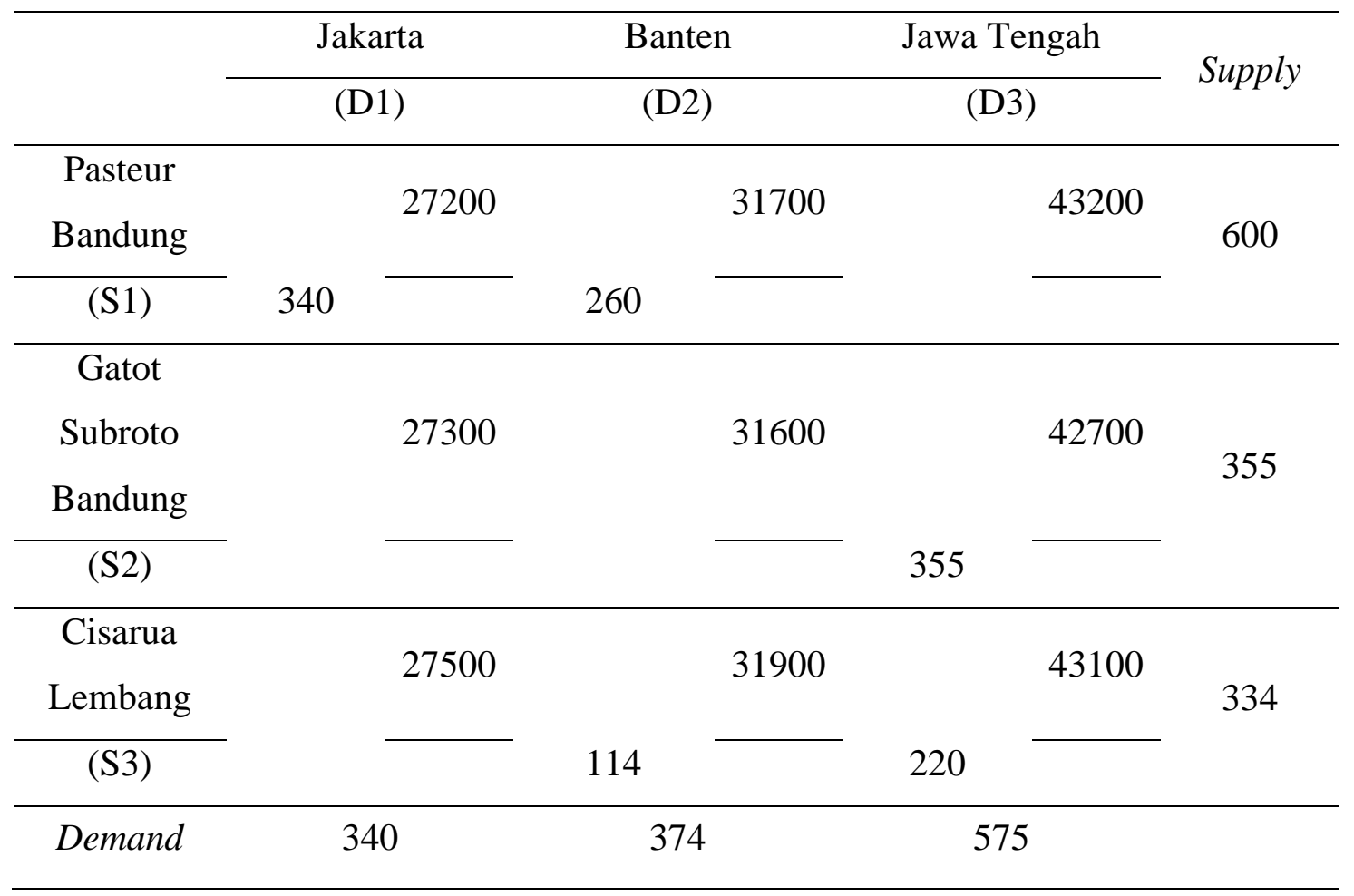

Iterasi 3

Asumsi U1 = 0

1. $\mathrm{C} 11=\mathrm{U} 1+\mathrm{V} 1 \rightarrow \mathrm{V} 1=\mathrm{C} 11-\mathrm{U} 1 \rightarrow \mathrm{V} 1=27200-0 \rightarrow \mathrm{V} 1=27200$

2. $\mathrm{C} 12=\mathrm{U} 1+\mathrm{V} 2 \rightarrow \mathrm{V} 2=\mathrm{C} 12-\mathrm{U} 1 \rightarrow \mathrm{V} 2=31700-0 \rightarrow \mathrm{V} 2=31700$

3. $\mathrm{C} 32=\mathrm{U} 3+\mathrm{V} 2 \rightarrow \mathrm{U} 3=\mathrm{C} 32-\mathrm{V} 2 \rightarrow \mathrm{U} 3=31900-31700 \rightarrow \mathrm{U} 3=200$

4. $\mathrm{C} 33=\mathrm{U} 3+\mathrm{V} 3 \rightarrow \mathrm{V} 3=\mathrm{C} 33-\mathrm{U} 3 \rightarrow \mathrm{V} 3=43100-200 \rightarrow \mathrm{V} 3=42900$

5. $\mathrm{C} 23=\mathrm{U} 2+\mathrm{V} 3 \rightarrow \mathrm{U} 2=\mathrm{C} 23-\mathrm{V} 3 \rightarrow \mathrm{U} 2=42700-42900 \rightarrow \mathrm{U} 2=-200$

Evaluasi Variabel non-basis :

$D_{i j}=c_{i j}-\left(u_{i}-v_{j}\right)$

1. $\mathrm{D} 13=\mathrm{C} 13-(\mathrm{U} 1+\mathrm{V} 3)=43200-(0+42900)=300$

2. $\mathrm{D} 21=\mathrm{C} 21-(\mathrm{U} 2+\mathrm{V} 1)=27300-(-200+27200)=300$

3. $\mathrm{D} 22=\mathrm{C} 22-(\mathrm{U} 2+\mathrm{V} 2)=31600-(-200+31700)=100$

4. $\mathrm{D} 31=\mathrm{C} 31-(\mathrm{U} 3+\mathrm{V} 1)=27500-(-200+27200)=100$ 
Jurnal Lebesgue : Jurnal Ilmiah Pendidikan Matematika, Matematika dan Statistika

Resa Lestari, Thyar Romadhon, Muchammad Fauzi

Volume 2, No. 2, Agustus 2021 hal.180-193

DOI Artikel : 10.46306/lb.v2i2.69

Tabel 10. Hasil Evaluasi Iterasi 3

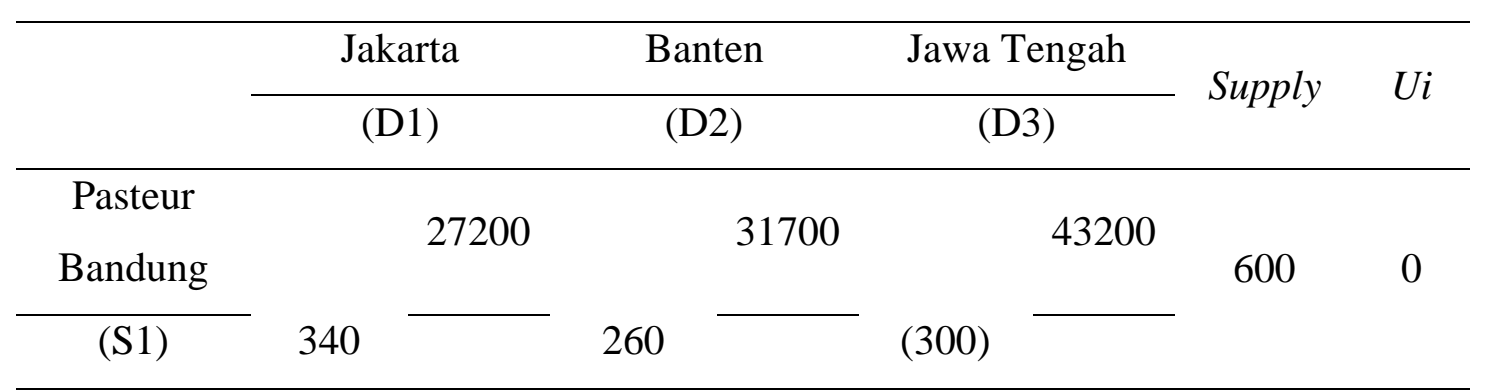

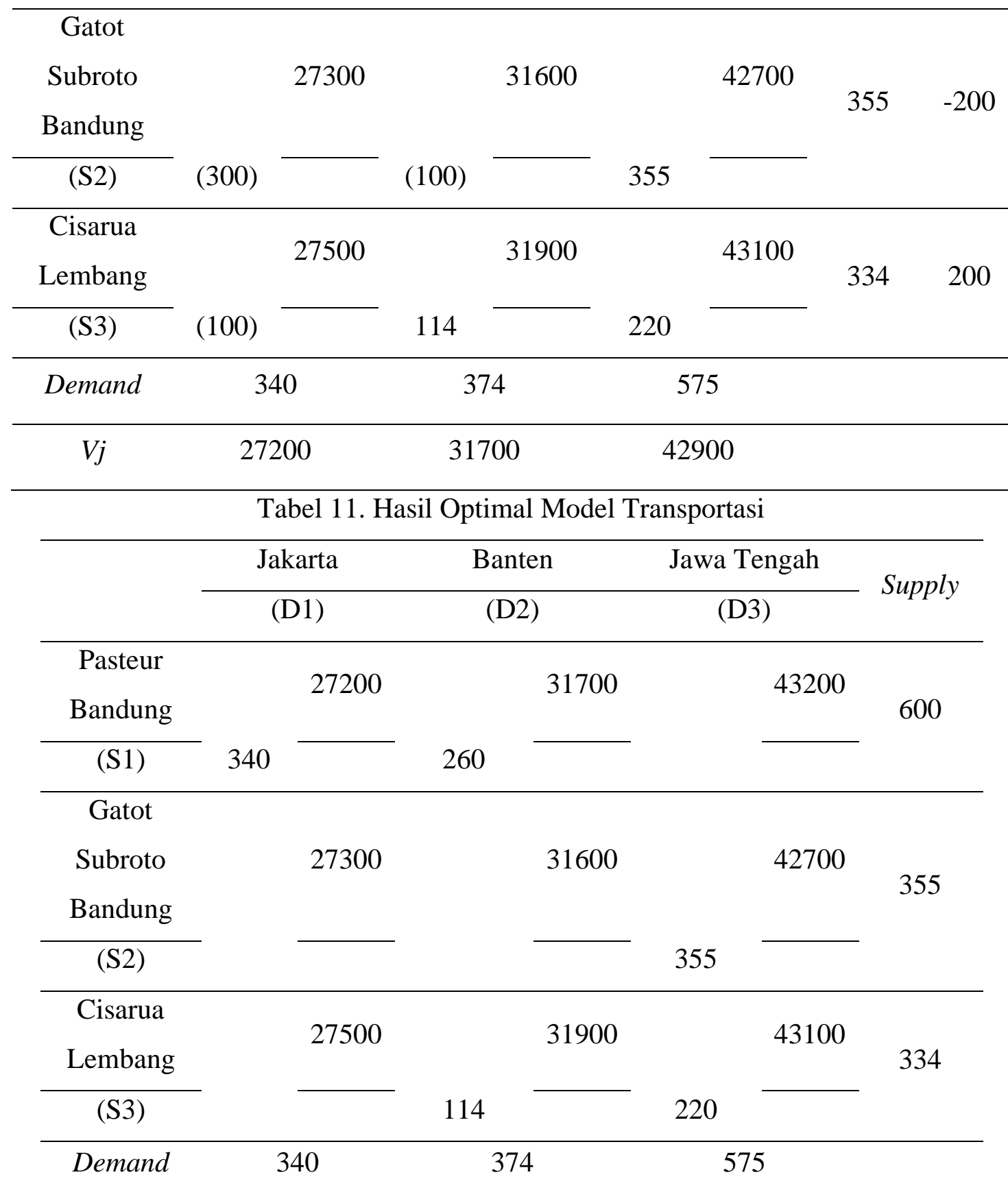

Karena variabel non-basis tidak memberi hasil negative, maka solusi optimal telah diperoleh dengan ongkos total transportasi sebesar. 
Jurnal Lebesgue : Jurnal Ilmiah Pendidikan Matematika, Matematika dan Statistika

Resa Lestari, Thyar Romadhon, Muchammad Fauzi

Volume 2, No. 2, Agustus 2021 hal.180-193

DOI Artikel : $10.46306 /$ lb.v2i2.69

$$
\begin{aligned}
& \text { OT }=\sum_{i=1, j=1}^{m, n} C i j . X i j \\
& \text { OT }=(27200 \times 340)+(31700 \times 260)+(42700 \times 355)+(31900 \times 114)+(43100 \times 220) \\
& \text { OT }=\operatorname{Rp} 45.767 .100
\end{aligned}
$$

\section{KESIMPULAN}

Implementasi model transportasi distribusi PT. XYZ dari ongkos transportasi pendistribusian kondisi awal sebesar Rp. 48.055.455 setelah dilakukan perhitungan solusi awal menggunakan Least Cost Method diperoleh biaya transportasi pendistribusian tiap bulan sebesar Rp. 45.874.900 kemudian dilakukan optimalisasi biaya dengan menggunakan Modified Distribution Method biaya transportasi pendistribusian tiap bulan menjadi lebih optimal menjadi sebesar Rp. 45.767.100, sehingga menghemat biaya transportasi pendistribusian sebanyak $5 \%$ dengan selisih penghematan sebesar Rp. 2.288.355. Berdasarkan hasil penghematan yang diperoleh, dengan solusi awal menggunakan Least Cost Method dan optimalisasi dengan menggunakan Modified Distribution Method tersebut efektif karena dapat meminimumkan biaya transportasi pendistribusian yang sebelumnya sebesar Rp. 48.055.455. Dengan pendistribusian yang optimal yaitu : 340 koli vaksin dari Pasteur Kota Bandung menuju ke Provinsi DKI Jakarta, 260 koli vaksin dari Pasteur Kota Bandung dan 114 koli dari Cisarua Lembang Kabupaten Bandung Barat menuju Provinsi Banten, 335 produk vaksin dari Gatot Subroto Kota Bandung dan 220 koli dari Cisarua Lembang Kabupaten Bandung Barat menuju Provinsi Jawa Tengah.

\section{DAFTAR PUSTAKA}

Ardiansyah, M. A. (2014). Penerapan Model Transportasi dan Distribusi Vogel's Approximation Method (VAM) Dan Modified Distribution (MODI) Pada PT. Hastura Nazwa Utama Di Bantaeng. Fakultas Ekonomi Dan Bisnis Universitas Hasanudin.

Herlawati. (2016). Optimasi Pendistribusian Barang Menggunakan Metode Stepping Stone dan Metode Modified Distribution ( MODI ). Information System for Educators and Professionals, 1(1), 103-113.

Irwan, H., \& Yuniral. (2016). Optimasi Penjadwalan Produksi dengan Metode Transportasi. Profiensi, 4(2), 79-89.

Matematika, D., Matematika, F., Ilmu, D. A. N., Alam, P., \& Utara, U. S. (2019). ANALISIS PENERAPAN MODEL TRANSPORTASI DENGAN METODE VOGEL APPROXIMATION ( VAM ) DENGAN UJI MODIFIED DISTRIBUTION ( MODI ) ANALISIS PENERAPAN MODEL TRANSPORTASI DENGAN METODE VOGEL APPROXIMATION ( VAM ) DENGAN UJI MODIFIED DISTRIBUTION ( MODI ).

Mulyono, S. (2007). Riset Operasi. Lembaga Penerbit Fakultas Ekonomi Universitas Indonesia. 
Nelwan, C., Kekenusa, J. S., \& Langi, Y. (2013). Optimasi Pendistribusian Air Dengan Menggunakan Metode Leave Cost dan Metode Modified Distribution. Jurnal Ilmiah Sains, 13(1), 45-51.

Putri, E. O., \& Putri, E. O. (2017). PENERAPAN METODE TRANSPORTASI VAM DAN MODI PADA PT. DOS NI ROHA SAMARINDA Eka Oktarina Putri, 2017.

Sari, D. permata. (2015). Optimasi Distribusi Gula Merah pada UD Sari Bumi Raya Menggunakan Model Transportasi dan Metode Least Cost. Jurnal Program Studi Sistem Informasi, 1-9.

Setyawam, D., \& Wicaksono, S. R. (2007). Penerapan Metode Modified Distribution Dalam Sistem Pendistribusian Barang Pada PT. Miswak Utama. Prosiding Seminar Nasional Sistem \& Teknologi Infromasi (SNASTI), 71-76.

Tirta, P. T., \& Perkasa, M. (n.d.). Penerapan Metode Modified Distribution ( MODI ) Dalam Meminimalisasi Biaya Transportasi Pengiriman Barang Di. 